\title{
A Comparative Study on the Effects of Risk Perception and Quality Perception on the Purchase Intention of Fashion Products in Online and Offline Shopping
}

\author{
Yanlin $\mathrm{Wu}^{1}$ ) Youngsook Lee²)
}

\begin{abstract}
Online shopping of fashion products has become an important way of purchase for Chinese consumers. However, consumers' satisfaction with convenient shopping will also be accompanied by the emergence of risk perception and quality perception. Offline shopping, as a traditional way of shopping, faces the challenge of online shopping, but it has gradually recovered in recent years. Because the fashion products in offline market can be judged directly, it can be speculated that the risk perception and quality perception in offline shopping is different from that in online shopping. Therefore, based on the comparison between online shopping and offline shopping, this paper intends to study the impact of risk perception and quality perception on consumers' purchase intention aimed at working women in their $20 \mathrm{~s}$ and $30 \mathrm{~s}$ in China. The responses from the sample were collected through survey questionnaires. The collected data were statistically processed through frequency analysis, reliability and validity analysis, factor analysis and correlation relationship analysis and the hypothesis verification of the structural equation model. Based on the results of the analysis of purchasing fashion products online, the factors of risk perception like the product information risk, economic risk, psychological risk and the factors of quality perception like the service quality and product quality have a positive effect on purchase intention. On the other hand, the analysis results of purchasing fashion products offline is that only the factor of risk perception like the product information risk has been shown to have a positive impact on purchase intention. This study is intended to help fashion companies to develop market strategies to on offline and online marketing.
\end{abstract}

Keywords: Online Shopping, Offline Shopping, Risk Perception, Quality Perception, Purchase Intention

\section{Introduction}

Today, increase in the reliance on personal computers and the Internet set a new trend toward the transfer of the traditional trading market to the internet market called "E-business." In China, the clothing market is shifting to mixed online and offline shopping, which features a

Received(May 26, 2020), Review Result(1st: July 17, 2020, 2nd: August 31, 2020), Accepted(September 25, 2020)

1) (Student) 48520 Dept. Fashion Design, Tongmyong University, 428 Sinseon-ro, Nam-gu, Busan, Korea email: 1067918022@qq.com

2) (Professor, Corresponding Author) 48520 Dept. Fashion Design, Tongmyong University, 428 Sinseon-ro, Nam-gu, Busan, Korea email: young@tu.ac.kr

*This paper summarizes part of the master's thesis. 
A Comparative Study on the Effects of Risk Perception and Quality Perception on the Purchase Intention of Fashion Products in Online and Offline Shopping

variety of goods, convenience of purchase, and consumers' risk perception and quality perception at the same time. According to the 2017-2018 Report on the Development of Retail Business in Chinese Department Store, Chinese people's increased personal income has changed consumers' consumption patterns, awakened the public's sense of quality and experience, reduced their price sensitivity, increased their pursuit of quality, and at the same time raised a number of dissatisfaction factors in the online shopping experience[1]. According to the United Nations' World Population Outlook 2017 Report, the largest number of women born between 1980 and 1989 (30s) in China was 1.93 million in 2017, and between 1990 and 1999 (20s) was 90.25 million[2].

In addition, according to Quest Mobile's analysis of Chinese Internet users, the total number of women using mobile networks was 531 million in January 2019, accounting for $46.9 \%$ of the entire website. Among them, 215 million women are in their 30s and 166 million women are in their 20s. The average monthly consumption of women in their 20s was 1,000RMB, accounting for $21.1 \%$ of the total, followed by $16.9 \%$ for women in their $30 \mathrm{~s}[3]$.

From this point of view, this study focused on women in the 20 s to 30 s, who are the most interested in fashion. This study intends to effectively investigate the effect of risk perception and quality perception on purchasing fashion products by consumers in online shopping and offline shopping, and find out if it is necessary to combine online shopping with offline shopping.

Previous studies tackled the effect of risk perception or quality perception on the purchase intention. In this study, the same topic is discussed but based on the comparison of online shopping and offline shopping.

This study will be carried out in the following steps. First, based on the theoretical context of the previous studies, this paper will analyze the concepts and types of risk and quality perception and understand the concept of purchase intention. Second, based on the responses of the sampled Chinese working women, this paper will study the impact of risk perception and quality perception on the purchase intention among consumers of fashion products on online and offline shopping. Finally, the results of this study would be able to help clothing companies establish effective marketing strategies on offline and online marketing.

\section{Theoretical Background}

Online shopping refers to searching and ordering products using the internet. Offline shopping malls refer to stores that contain traditional business circles and to actual markets that 
consumers can see on the street[4]. In online shopping, consumers do not shop directly in the actual market, but rather purchase in virtual spaces where comparative products and other online services are available for them[5]. This shopping method features shopping convenience, home delivery concept, online catalog, and produc review[6]. However, as the demand of online shopping increases, so do consumers' adaptations. Thus, this platform requires strong technical support to reassure consumers on the stability and security of the online market.

Risk perception is a subjective perception of uncertainty about the result of purchase and the consequent loss of expected value[7]. The study of risk perception has always been an important theme in marketing to circumvent or minimize the occurrence of high risk[8].

Form the previous studies, there are five types of risk perception namely product information risk, economic risk, personal information risk, psychological risk, and functional risk [9-11].

Depending on the consumer's perceived level, the product quality by function and the perceived quality by the consumer can be very different, confirming that these concepts can be described as perceived quality[12]. Quality perception refers to consumers' perception that a product or service is generally superior to other alternative products or services in relation to its use[13].

From the previous studies, quality perception have two types namely product quality and service quality[14][15].

The purchase intention is the intention to purchase the product and it is considered as an important step for the purchase of consumer[16]. The intention to buy a product is the intention of consumers to have some degree of future action and purchasing a product is the consumer's belief and attitude towards it. The consumer's intention to buy a product has a greater impact on the decision than on the attitude of the product itself[17].

\section{Research Method}

\subsection{Research Model and Hypothesis}

This study aimed to conduct empirical studies on working women in their $20 \mathrm{~s}$ and $30 \mathrm{~s}$ in China to find out how risk perception (product information risk, economic risk, personal information risk, psychological risk, functional risk) and quality perception (service quality, product quality) affect their purchase intentions when purchasing fashion products in online shopping and offline shopping. In order to achieve this goal, the following hypothesis are set:

Hypothesis 1: When purchasing fashion products in online shopping, risk perception has a 
A Comparative Study on the Effects of Risk Perception and Quality Perception on the Purchase Intention of Fashion Products in Online and Offline Shopping

positive effect on purchasing intention of the consumers.

Hypothesis 2: When purchasing fashion products in online shopping, quality perception has a positive effect on purchasing intention of the consumers.

Hypothesis 3: When purchasing fashion products in offline shopping, risk perception has a positive effect on purchasing intention of the consumers.

Hypothesis 4: When purchasing fashion products in offline shopping, quality perception has a positive effect on purchasing intention of the consumers.

\subsection{The Subject of Study and Measurement Method}

This study conducted a survey aimed at working women in their 20s and 30s in China on February 2019. The responses from the sample were collected through survey questionnaires using internet. A total of 320 copies of the questionnaire were distributed in which 317 copies were recovered and 312 copies were used for the final analysis.

This paper used the questionnaire from the previous studies, which was revised by researcher and improved to 20 risk perception related questions, 11 quality perception related questions, and 6 purchase intention related questions. Also, it used the five-point Likert scale to determine the level of agreement of the respondents. The statistical processing of the collected data including the frequency analysis, reliability validity analysis, factor analysis and correlation relationship analysis were carried out using SPSS 22.0 for Windows. The hypothesis verification of the structural equation model was carried out by using AMOS 23.

\section{Results}

\subsection{Frequency Analysis}

According to the demographic characteristics of the respondents, 41 people $(13.1 \%)$ are in the first half of the 20s $(39.4 \%), 123$ people $(39.4 \%)$ in the second half of the 20s, 114 people (36.5 percent) in the first half of the 30s, and 34 people $(10.9 \%)$ in the second half of the $30 \mathrm{~s}$. Among the professional groups, 133 people (42.6\%) are white collar workers and $74(23.7 \%)$ full-time workers. There are 148 people $(47.4 \%)$ with an average monthly income of 5,000 to $8,000 \mathrm{RMB}(47.4 \%)$, and 99 people with an average monthly income of 8000 to $11000 \mathrm{RMB}$ $(31.7 \%)$. There are 130 people who spent 500 to $1,000 \mathrm{RMB}(41.7 \%)$ on clothes at an average time, and 101 people spent 1000 to $1500 \mathrm{RMB}$ (32.4\%) on clothes at an average time. 


\subsection{Reliability and Validity Analysis}

In this study, the reliability analysis in [Table 1] shows that the Cronbach's a coefficient for each item was 0.5 or higher, thus reliability for the questionnaire is ensured. In this study, the $\mathrm{KMO}$ and Bartlett tests were first used to determine whether the number of samples and independent variables were appropriate for analysis, and then the factor analysis was conducted. When purchasing fashion products for online and offline shopping, as shown in [Table 2], the KMO value for risk perception was 0.84 , for quality perception was 0.912 , for purchase intention was 0.801 , which all indicate that the range of $\mathrm{KMO}$ values was between 0 and 1 , and that the variables were highly correlated and effective.

\subsection{Factor Analysis}

In this study, the main component analysis was used for factor extraction, and the varimax method, which is orthogonal rotation, was used for factor rotation. Based on the analysis of the factors that appear in online shopping and offline shopping, the risk perception of independent variables in [Table 3] shows a factor load value of 0.512 or higher, an eigen value of 1.0 or higher, and obtained five valid variables. These five variables (product information perception, economic perception, personal information perception, psychological perception, functional perception) show a cumulative $64.89 \%$ percent common dispersion.

The quality perception in [Table 4] shows a factor load value of 0.573 or higher, an eigen value of 1.0 or higher, and obtained two valid variables. These two variables (service quality, product quality) showed a cumulative $58.44 \%$ common dispersion.

The intention of purchase in [Table 5] shows a factor load value of 0.694 or higher, an eigen value of 1.0 or higher, and obtained one valid variable. This variable showed a cumulative $68.936 \%$ common dispersion.

\subsection{Correlation Analysis}

Pearson Correlation is commonly used primarily to find relevance between two variables. In this study, the Pearson correlation number was analyzed to determine the relationship between risk perception, quality perception and purchase intention. The results are as follows:

As shown in [Table 6], a related relationship is proposed based on the average of the major variables in online shopping. All variables like risk perception, quality perception and purchase 
A Comparative Study on the Effects of Risk Perception and Quality Perception on the Purchase Intention of Fashion Products in Online and Offline Shopping

intention showed positive $(+)$ relationship with the variables in situations where they were statistically significant at a significant level of 0.000 .

Therefore, the overall observation of the correlation between all variables in online shopping shows that there is no problem in the validity of the variables, and that all correlations between the variables are meaningful and appropriate.

As shown in [Table 7], a related relationship is proposed based on the average of the major variables in offline shopping. All variables like risk perception, quality perception and purchase intention showed positive $(+)$ relationship with the variables in situations where they were statistically significant at a significant level of 0.000 .

Therefore, the overall observation of the correlation between all variables in offline shopping shows that there is no problem in the validity of the variables, and that all correlations between the variables are meaningful and appropriate.

\subsection{Hypothesis Verification Through the Analytical Result}

This study has applied a structural equation (SEM) through AMOS (Structural Equation Modelling: SEM) to verify the risk perception, quality perception, and purchase intention of Chinese working women in their 20s and 30s purchasing through online and offline shopping. The suitability of the model for the study is shown in [Table 8] and [Table 9].

In terms of online shopping, [Table 8] shows that the factors of risk perception including product information perception, economic perception, psychological perception, and quality perception factors including service quality and product quality all have a positive $(+)$ effect on purchase intention.

In terms of offline shopping, [Table 9] shows that the factors of risk perception including product information perception, economic perception, personal information perception, functional perception and the factor of quality perception, product quality have a positive $(+)$ effect on purchase intention.

[Table 1] Reliability Analysis

\begin{tabular}{c|c|c|c}
\hline Factor & Variables & Number of Questions & Cronbach's a(n=312) \\
\hline \multirow{4}{*}{ Risk Perception } & Product Information Risk & 4 & 0.797 \\
& Economic Risk Personal & 4 & 0.629 \\
& Personal Information Risk & 4 & 0.570 \\
& Psychological Risk & 4 & 0.829 \\
& Functional Risk & 4 & 0.840 \\
\hline Quality Perception & Service Quality & 6 & 0.838 \\
& Product Quality & 5 & 0.813 \\
\hline Purchase Intention & Purchase Intention & 6 & 0.810 \\
\hline
\end{tabular}




\begin{tabular}{c|c}
\hline Factor & Gaiser-Meyer-Olkin Measures of Sample Adequacy \\
\hline Risk Perception & .840 \\
Quality Perception & .912 \\
Purchase Intention & .801 \\
\hline
\end{tabular}

[Table 3] Factor Analysis on Risk Perception

\begin{tabular}{|c|c|c|c|c|c|}
\hline \multirow{3}{*}{ Item } & \multicolumn{5}{|c|}{ I. Risk Perception } \\
\hline & $\begin{array}{c}\text { Product } \\
\text { Information }\end{array}$ & $\begin{array}{c}\text { Econo } \\
\text {-mic }\end{array}$ & \begin{tabular}{|c|} 
Personal \\
Information
\end{tabular} & $\begin{array}{l}\text { Psychol } \\
\text {-ogical }\end{array}$ & $\begin{array}{l}\text { Funct } \\
\text {-ional }\end{array}$ \\
\hline & Risk & Risk & Risk & Risk & Risk \\
\hline $\begin{array}{l}\text { I -19 am worried that the product will be bleached and } \\
\text { altered after washing. }\end{array}$ & .824 & .194 & .085 & .055 & .080 \\
\hline $\begin{array}{l}\text { I -17 I am worried to discover the defects of the goods that } \\
\text { were previously unknown after purchase. }\end{array}$ & .789 & .219 & .163 & .063 & .177 \\
\hline I -20 $\left[\begin{array}{l}\text { I'm worried that the product won't satisfy my } \\
\text { expectations or desires compared to the cost. }\end{array}\right.$ & .756 & .223 & .053 & 126 & .027 \\
\hline $\begin{array}{l}\text { I -18 I'm worried that the goods will not function properly } \\
\text { and cause financial loss. }\end{array}$ & .561 & .382 & .219 & .075 & .230 \\
\hline I -16 $\left[\begin{array}{l}\text { I'm worried I can't wear long because of the change in } \\
\text { fashion. }\end{array}\right.$ & .160 & .822 & .007 & .122 & .101 \\
\hline 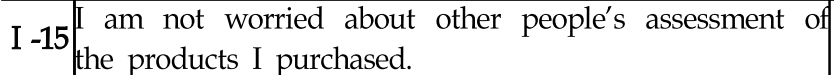 & .230 & .808 & .017 & 155 & .054 \\
\hline I -8 I am worried to enter a credit card number. & .119 & .073 & .087 & .065 & .855 \\
\hline I -14 [ I am worried that the product I want to buy will suit & .352 & 641 & .052 & .173 & .072 \\
\hline I -13 I'm afraid this product doesn't go well with what & .448 & .578 & .125 & 141 & .070 \\
\hline I -2 Prompt delivery of new product information. & .199 & .040 & .813 & 128 & 127 \\
\hline \begin{tabular}{l|l} 
I -1 & Provide sufficient information \\
\end{tabular} & .018 & .136 & .754 & .260 & .192 \\
\hline I -3 $\begin{array}{l}\text { It is convenient to get information about the fashion } \\
\text { products I want to purchase. }\end{array}$ & .254 & -.084 & .731 & .253 & .039 \\
\hline $\begin{array}{l}\text { I -11 Stores try to update the members' personal information } \\
\text { to prevent leakage. }\end{array}$ & 270 & .028 & .035 & .740 & 167 \\
\hline $\begin{array}{l}\text { I -6 } \\
\begin{array}{l}\text { Membership information is well protected for the } \\
\text { fashion brand I am using. }\end{array}\end{array}$ & -.012 & .140 & .276 & .738 & .055 \\
\hline $\begin{array}{l}\text { I -5 The information security system is trusted and reliable, } \\
\text { and the payment method is safe. }\end{array}$ & 158 & .091 & .351 & .681 & -.002 \\
\hline I -4 I trust the information provided by the brand. & -.064 & .194 & .475 & .530 & .033 \\
\hline $\begin{array}{l}\text { I -10 Personal information may be provided in order to } \\
\text { obtain preferential information on the goods. }\end{array}$ & .016 & .299 & .072 & .512 & .113 \\
\hline $\begin{array}{l}\text { I -7 I am afraid that the information on my credit card will } \\
\text { be leaked and I will lose money. }\end{array}$ & -.067 & .307 & .258 & -.022 & .729 \\
\hline $\begin{array}{l}\text { I -12 If personal information is requested, the purchase will } \\
\text { be abandoned }\end{array}$ & .115 & -.047 & -.155 & .330 & .692 \\
\hline $\begin{array}{l}\text { I -9 I am worried that my personal information being used } \\
\text { elsewhere }\end{array}$ & .335 & .042 & .302 & .029 & .686 \\
\hline Eigen value & 6.33 & 2.35 & 1.83 & 1.41 & 1.04 \\
\hline$\%$ of variance & 31.67 & 11.77 & 9.18 & 7.06 & 5.19 \\
\hline Cumulative $\%$ of Variance & 31.67 & 43.44 & 52.63 & 59.69 & 64.89 \\
\hline
\end{tabular}


A Comparative Study on the Effects of Risk Perception and Quality Perception on the Purchase Intention of Fashion Products in Online and Offline Shopping

[Table 4] Factor Analysis on Quality Perception

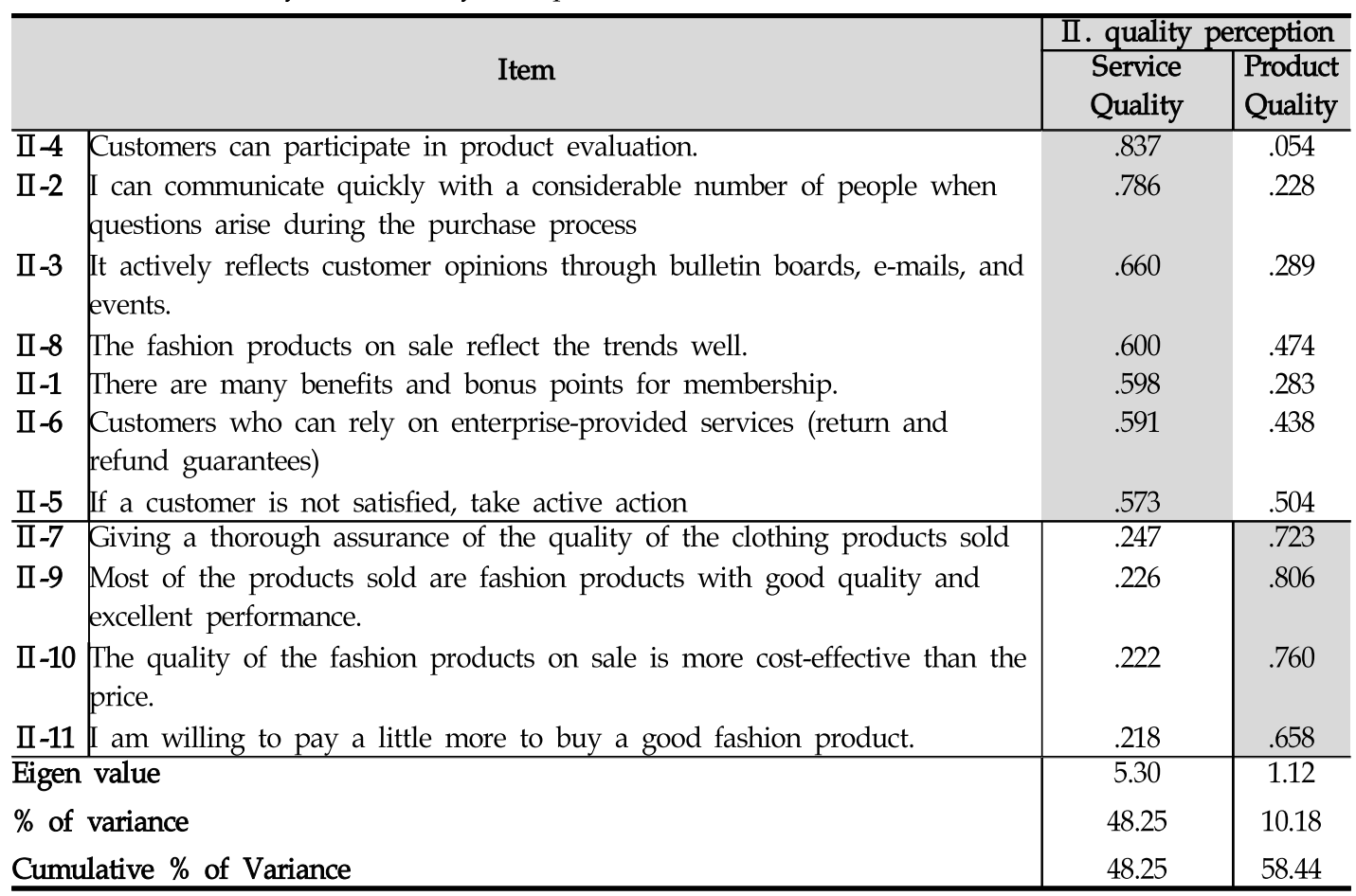

[Table 5] Factor Analysis on Purchase Intention

\begin{tabular}{l|l|c|c}
\hline \multicolumn{1}{c|}{ Item } & \multicolumn{1}{c}{ III.Purchase Intention } \\
\hline III-1 & I tend to buy new styles of clothes as soon as they become popular. & .119 & .878 \\
III-2 & $\begin{array}{l}\text { I only care about online shopping malls and shopping malls that offer } \\
\text { discounts when buying clothes and fashion products }\end{array}$ & .268 & .820 \\
III-6 & $\begin{array}{l}\text { I will often buy the products I need in online shopping or offline } \\
\text { shopping }\end{array}$ & .815 & .062 \\
III-5 & $\begin{array}{l}\text { I will actively look for product information in internet shopping malls and } \\
\text { stores to purchase necessary products. }\end{array}$ & .806 & .161 \\
III-4 & $\begin{array}{l}\text { If I am satisfied with the service offers (points, coupons, event offers) } \\
\text { buying them. }\end{array}$ & .753 & .248 \\
III-3 & $\begin{array}{l}\text { For me Promotion of online shopping malls and shopping malls (various } \\
\text { discounts/buying discounts) can trigger an impulse to buy }\end{array}$ & .694 & .394 \\
\hline \hline $\begin{array}{l}\text { Eigen value } \\
\text { \% of variance } \\
\text { Cumulative } \% \text { of Variance }\end{array}$ & 3.10 & 1.03 \\
\hline
\end{tabular}


[Table 6] Correlation by Mean Value of Key Variables (Online Shopping)

http://dx.doi.org/10.47116/apjcri.2020.10.09

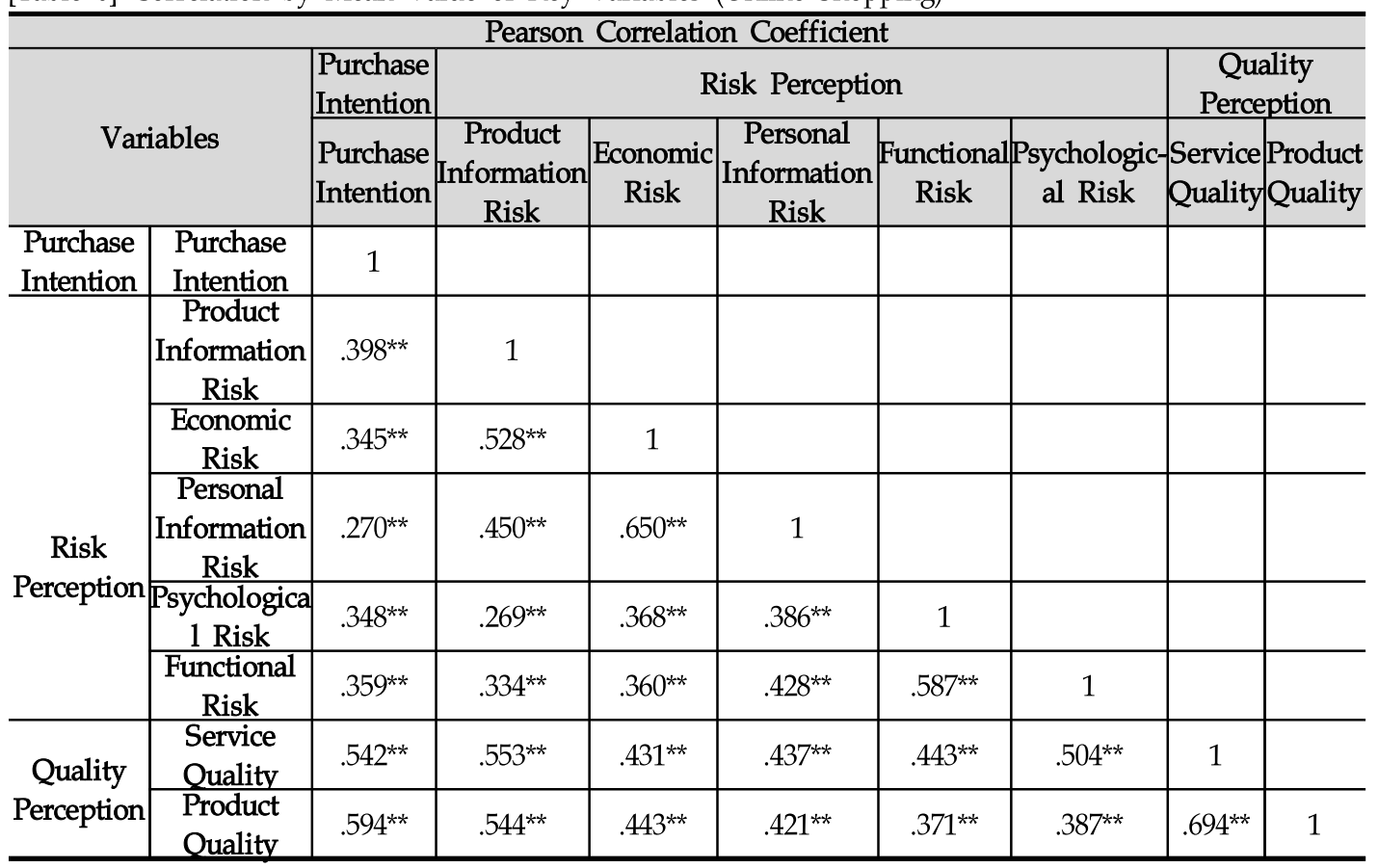

[Table 7] Correlation by Mean Value of Key Variables (Offline Shopping)

\begin{tabular}{|c|c|c|c|c|c|c|c|c|c|}
\hline \multicolumn{10}{|c|}{ Pearson Correlation Coefficient } \\
\hline \multirow{2}{*}{\multicolumn{2}{|c|}{ Variables }} & \begin{tabular}{|l|} 
Purchase \\
Intention
\end{tabular} & \multicolumn{5}{|c|}{ Risk Perception } & \multicolumn{2}{|c|}{$\begin{array}{c}\text { Quality } \\
\text { Perception }\end{array}$} \\
\hline & & $\begin{array}{l}\text { Purchase } \\
\text { Intention }\end{array}$ & \begin{tabular}{|c|}
$\begin{array}{c}\text { Product } \\
\text { Information } \\
\text { Risk }\end{array}$ \\
\end{tabular} & $\begin{array}{c}\text { Economic } \\
\text { Risk }\end{array}$ & \begin{tabular}{|c|} 
Personal \\
Information \\
Risk \\
\end{tabular} & $\begin{array}{c}\text { Functional } \\
\text { Risk }\end{array}$ & $\begin{array}{l}\text { Psychologic } \\
\text {-al Risk }\end{array}$ & Service & $\begin{array}{l}\text { Product } \\
\text { Quality }\end{array}$ \\
\hline $\begin{array}{l}\text { Purchase } \\
\text { Intention }\end{array}$ & $\begin{array}{l}\text { Purchase } \\
\text { Intention }\end{array}$ & 1 & & & & & & & \\
\hline \multirow{5}{*}{$\begin{array}{c}\text { Risk } \\
\text { Perception }\end{array}$} & \begin{tabular}{|c|} 
Product \\
Information \\
Risk
\end{tabular} & $.505^{* *}$ & 1 & & & & & & \\
\hline & $\begin{array}{c}\text { Economic } \\
\text { Risk }\end{array}$ & $.464^{* *}$ & $.508^{* *}$ & 1 & & & & & \\
\hline & \begin{tabular}{|c|} 
Personal \\
Information \\
Risk
\end{tabular} & $.489^{* *}$ & $.457^{* *}$ & $.717^{* *}$ & 1 & & & & \\
\hline & $\begin{array}{c}\text { Psychological } \\
\text { Risk }\end{array}$ & $.397^{* *}$ & $.323^{* *}$ & $.522^{* *}$ & $.513^{* *}$ & 1 & & & \\
\hline & \begin{tabular}{|c|} 
Functional \\
Risk
\end{tabular} & $.400^{* *}$ & $.352^{* *}$ & $.573^{* *}$ & $.567^{* *}$ & $.712^{* *}$ & 1 & & \\
\hline \multirow[b]{2}{*}{$\begin{array}{c}\text { Quality } \\
\text { Perception }\end{array}$} & $\begin{array}{l}\text { Service } \\
\text { Quality }\end{array}$ & $.524^{* *}$ & $.520^{* *}$ & $.540^{* *}$ & $.540^{* *}$ & $.404^{* *}$ & $.475^{* *}$ & 1 & \\
\hline & $\begin{array}{l}\text { Product } \\
\text { Quality }\end{array}$ & $.498^{* *}$ & $.569^{* *}$ & $.544^{* *}$ & $.563^{* *}$ & $.435^{* *}$ & $.480^{* *}$ & $.724^{* *}$ & 1 \\
\hline
\end{tabular}


A Comparative Study on the Effects of Risk Perception and Quality Perception on the Purchase Intention of Fashion Products in Online and Offline Shopping

[Table 8] Verification Result of Path Analysis (Online Shopping)

\begin{tabular}{|c|c|c|c|c|c|c|c|c|}
\hline \multicolumn{4}{|c|}{ Hypothesis Relation } & $\begin{array}{c}\text { Coefficient of } \\
\text { Path }\end{array}$ & $\begin{array}{l}\text { Standard } \\
\text { error }\end{array}$ & $t$ & $P$ & Hypothesis \\
\hline $\mathrm{H} 1-1$ & $\begin{array}{c}\text { Product } \\
\text { Information } \\
\text { Risk }\end{array}$ & $->$ & $\begin{array}{l}\text { Purchase } \\
\text { Intention }\end{array}$ & 0.877 & 0.055 & 21.02 & $* * *$ & Adopted \\
\hline $\mathrm{H} 1-2$ & Economic Risk & $->$ & $\begin{array}{l}\text { Purchase } \\
\text { Intention }\end{array}$ & -0.11 & 0.059 & -2.486 & 0.013 & Adopted \\
\hline $\mathrm{H} 1-3$ & $\begin{array}{l}\text { Personal } \\
\text { Information } \\
\text { Risk }\end{array}$ & $->$ & $\begin{array}{l}\text { Purchase } \\
\text { Intention }\end{array}$ & 0.009 & 0.061 & 0.205 & 0.837 & Rejected \\
\hline $\mathrm{H} 1-4$ & $\begin{array}{l}\text { Psychological } \\
\text { Risk }\end{array}$ & $->$ & $\begin{array}{l}\text { Purchase } \\
\text { Intention }\end{array}$ & -0.081 & 0.044 & -2.021 & 0.043 & Adopted \\
\hline $\mathrm{H} 1-5$ & $\begin{array}{l}\text { Functional } \\
\text { Risk }\end{array}$ & $->$ & $\begin{array}{l}\text { Purchase } \\
\text { Intention }\end{array}$ & 0.081 & 0.049 & 1.937 & 0.053 & Rejected \\
\hline $\mathrm{H} 2-1$ & $\begin{array}{l}\text { Service } \\
\text { Quality }\end{array}$ & $->$ & $\begin{array}{l}\text { Purchase } \\
\text { Intention }\end{array}$ & 0.125 & 0.07 & 2.585 & 0.01 & Adopted \\
\hline $\mathrm{H} 2-2$ & $\begin{array}{l}\text { Product } \\
\text { Quality }\end{array}$ & $->$ & $\begin{array}{l}\text { Purchase } \\
\text { Intention }\end{array}$ & -0.145 & 0.065 & -3.172 & 0.002 & Adopted \\
\hline
\end{tabular}

[Table 9] Verification Result of Path Analysis (Offline Shopping)

\begin{tabular}{|c|c|c|c|c|c|c|c|c|}
\hline \multicolumn{4}{|c|}{ hypothesis relation } & \multirow{2}{*}{\begin{tabular}{|c|}
$\begin{array}{c}\text { coefficient of } \\
\text { path }\end{array}$ \\
0.236
\end{tabular}} & \multirow{2}{*}{$\begin{array}{c}\text { standard error } \\
0.092\end{array}$} & \multirow{2}{*}{$\frac{\mathrm{t}}{3.473}$} & \multirow{2}{*}{$\begin{array}{l}\mathrm{P} \\
* *\end{array}$} & \multirow{2}{*}{\begin{tabular}{|l} 
hypothesis \\
Adopted
\end{tabular}} \\
\hline H3-1 & $\begin{array}{l}\text { Product } \\
\text { Information } \\
\text { Risk }\end{array}$ & $->$ & $\begin{array}{l}\text { Purchase } \\
\text { Intention }\end{array}$ & & & & & \\
\hline $\mathrm{H} 3-2$ & Economic Risl & & $\begin{array}{l}\text { Purchase } \\
\text { Intention }\end{array}$ & 0.119 & 0.119 & 1.426 & 0.154 & Rejected \\
\hline $\mathrm{H} 3-3$ & $\begin{array}{l}\text { Personal } \\
\text { Information } \\
\text { Risk }\end{array}$ & $->$ & $\begin{array}{l}\text { Purchase } \\
\text { Intention }\end{array}$ & 0.004 & 0.121 & 0.048 & 0.962 & Rejected \\
\hline $\mathrm{H} 3-4$ & $\begin{array}{l}\text { Personal } \\
\text { Information } \\
\text { Risk }\end{array}$ & $\rightarrow$ & $\begin{array}{l}\text { Purchase } \\
\text { Intention }\end{array}$ & -0.068 & 0.086 & -0.88 & 0.379 & Rejected \\
\hline $\mathrm{H} 3-5$ & $\begin{array}{l}\text { Functional } \\
\text { Risk }\end{array}$ & $\rightarrow$ & $\begin{array}{l}\text { Purchase } \\
\text { Intention }\end{array}$ & 0.066 & 0.096 & 0.805 & 0.421 & Rejected \\
\hline $\begin{array}{l}\text { Service } \\
\text { Quality }\end{array}$ & $\begin{array}{l}\text { Service } \\
\text { Quality }\end{array}$ & $\rightarrow$ & $\begin{array}{l}\text { Purchase } \\
\text { Intention }\end{array}$ & -0.066 & 0.111 & -0.813 & 0.416 & Rejected \\
\hline $\mathrm{H} 4-2$ & $\begin{array}{l}\text { Product } \\
\text { Quality }\end{array}$ & $->$ & $\begin{array}{l}\text { Purchase } \\
\text { Intention }\end{array}$ & 0.097 & 0.126 & 1.145 & 0.252 & Rejected \\
\hline
\end{tabular}




\section{Conclusion and Proposal}

With the continuous development of China's online shopping, a lot of clothing brands are from offline to online. Products in online are variety and convenient to purchase which attracted more and more consumers shopping in online, especially attracted a large number of $20 \mathrm{~s}-30 \mathrm{~s}$ working women whose relative consumption ability but time is not enough, and the online shopping brings great convenience to them. Therefore, it is necessary to study online shopping for fashion products. However, online shopping is virtual shopping, and its potential risks may affect consumers' purchase intention. Different from online shopping, products in offline shopping market can be directly touched, which can reduce the risk of failure for shopping and this is also one of the important reasons for the gradual recovery of offline shopping market in recent years. Therefore, this paper aimed to compare the impact of consumers' risk perception and quality perception on purchase intention in the process of buying fashion products online and offline. In order to achieve this goal, the research sequence of this paper is as follow.

First, the demographic characteristics of the respondents are known through frequency analysis.

Second, Reliability for the questionnaire is ensured by reliability analysis and the variables like risk perception, quality perception and purchase intention proved to be highly correlated and effective in validity analysis.

Thirdly, There are five variables like product information perception, economic perception, personal information perception, psychological perception, functional perception of risk perception, and two variables like service quality, product quality of quality perception and variable likes purchase intention were obtained by factors analysis.

Fourth, Through correlation analysis, it is proved that risk perception, quality perception and purchase intention showed positive $(+)$ relationship in online shopping and offline shopping and they were statistically significant.

In the end, the results of the impact of risk perception and quality perception on purchase intention of women consumers in their 20s and 30s who buy fashion products online and offline were obtained through analyzing the structural equation. According to the comparative study, only the product information risk has a positive $\left(^{+}\right)$influence on the purchase intention in offline shopping, while the product information risk, economic risk, psychological risk, service quality and product quality all have a positive $(+)$ influence on the purchase intention 
A Comparative Study on the Effects of Risk Perception and Quality Perception on the Purchase Intention of Fashion Products in Online and Offline Shopping

in online shopping.

Therefore, it can be judged that risk perception and quality perception in online shopping have more influences on purchase intention than offline shopping. Based on this result, it can be inferred that reducing risk perception and improving quality perception in online shopping have a positive effect on improving consumers' purchase intention. Based on the research data of this paper could provide meaningful reference value for apparel enterprises when making online marketing strategies.

Finally, the survey conducted for this study was limited to female consumers aged 20 and 30 living in Beijing, China. Therefore this study does not reflect the attitude of all female consumers aged 20 and 30. Careful analysis and interpretation of the results are required to come up with an appropriate conclusion based on the number of respondents.

\section{References}

[1] 2018 China Fashion Digitalization Retail Research Report, http://www.199it.com/archives/814520.html, Jan 3 (2019)

[2] World Population Prospects of 2017, https://population.un.org/wpp/Publications/Files/WPP2017_DataBooklet. pdf, Jan 3 (2019)

[3] QuestMobile, Her economic insight report, https:/www.questmobile.com.cn/research/report-new/24, Mar 27 (2019)

[4] Joo Nam Yoo, Comparison research on brand images of online and offline shopping mall -around SPA brands, Sungkyunkwan University, Master's Thesis, (2015)

[5] Soo-ji Lee, A Comparative Analysis on the Relationship between the Perceived Quality of Service and Customer Satisfaction, Trust and Relationship of Online and Offline Shopping Mall Sports Wear Buyers, Chonnam National University, Ph.D dissertation, (2012)

[6] Wu Baofu, Ch. Sai Ramnadh, Hye-jin Kim, Consumer Perception and Satisfaction towards Online Shopping, International Journal of Smart Business and Technology, (2014), Vol.2, No.2, pp.35-42.

[7] Joo-hee Kim, Jong-kyung Ha, Purchase Behavior and Risk Perception in Cosmetics Purchases at Online Shopping Malls, Korean Journal of Human Ecology, (2010), Vol.19, No.6, pp.1003-1012.

[8] Young Soo Heo, A Study on Relationships among Purchase Cues, Perceived Risks and Purchase Intent, Dankook University, Master's Thesis, (2015)

[9] Sun-hee Cho, The effect of product's intangibility on risk perception and risk reduction behaviors of consumers and the moderating effect of self-regulatory, Kyungpook National University, Master's Thesis, (2012) 
[10] Chae-Kwan Lim, Kyeng-Bong, The Effect of Service Quality of Legal Services on Customer Satisfaction, International Journal of Smart Business and Technology, (2017), Vol.5, No.2, p.714.

[11] Wei Mei Ang, The effect of Perceived Risk on consumer impulse buying in online shopping mall -Focused on the moderating role of BRQ, Woosong University, Master's Thesis, (2018)

[12] Sul Min Yoon, Choong Ki Lee, The Relationship between Festival Experience, Perceptual Quality, Perceptual Value, and Emotional Immergence Based on the Experience Economy (4Es) Perspective: Focused on the 2016 Seoul Light-Elong Festival, Degree in the Management of Korean Government Authority, (2017), Vol.32, No.5, pp.79-96.

[13] Hye Young Kim, Customer satisfaction and perceived quality of the product of the Influence on Repurchase: Focusing on skin care cosmetics, Seokyeong University, Master's Thesis, (2011)

[14] Hyun Jin Kim, The Effect of The Quality Certification on Purchase Intention, Soongsil University, Master's Thesis, (2010)

[15] Tae-Hyup Roh, Hwa-Yeol Choi, The Study on the effect of Service Quality of Domestic Ticket Payment Application on Satisfaction and Purchasing Intention, International Journal of IT-based Business Strategy and Management, (2018), Vol.4, No.1, pp.41-46.

[16] Chao Ding, Young-Sook Lee, The Effect of Chinese College Students on Korean Brand Preference and Purchase Intention - Focusing on the Images of Fashion Products in Korean Dramas, International Journal of Business Policy and Strategy Management, (2017), Vol.4, No.2, pp.39-46.

[17] Kun-hee Lee, The Influence of PPL Characteristics on Brand Preference and Intention of Cosmetics: Focusing on Chinese Tourists, Chung-Ang University, Master's Thesis, (2015) 